\title{
Management of Atypical Squamous Cell Cases: A Prospective Study of Women seen at a Private Health Service in Northeastern Brazil
}

\section{Conduta em casos de células escamosas atípicas: um estudo prospectivo de mulheres atendidas pelo serviço de saúde privado no nordeste do Brasil}

\author{
Geilson Gomes de Oliveira ${ }^{1}$ Judite Maria da Silva Costa de Oliveira ${ }^{1}$ Renata Mirian Nunes Eleutério ${ }^{2}$ \\ José Eleutério Júnior ${ }^{1,3}$
}

\footnotetext{
1 Department of Pathology, Universidade Federal do Ceará, Fortaleza, Brazil

2 Department of Pharmacy, Universidade Federal do Ceará, Fortaleza, Brazil

${ }^{3}$ Department of Motherhood and Child, Universidade Federal do

Ceará, Fortaleza, Brazil
}

Address for correspondence Geilson Gomes de Oliveira, MSc, Universidade Federal do Ceará, Rua Aluísio Borba, 132, Casa 4, Fortaleza, CE, 60813-730, Brazil (e-mail: geilson.ce@gmail.com).

Rev Bras Ginecol Obstet 2018;40:121-126.

\begin{abstract}
Keywords

- uterine cervical neoplasm

- disease management

- atypical squamous cells of the cervix

- papanicolaou test

- human papillomavirus

Objective To assess the management chosen by gynecologists after atypical squamous cells (ASCs) cytology results, and to evaluate the outcomes of these cases in Brazilian women.

Methods A prospective observational study evaluated the initial management offered by the gynecologist in the case of 2,458 ASCs cytology results collected between January of 2010 and July of 2016. The outcomes of the cytology, high-risk human papilloma virus (HR-HPV) test and histology were compared in two subgroups: atypical squamous cells of undetermined significance (ASC-US) and atypical squamous cells-cannot exclude high-grade squamous intraepithelial lesion (ASC-H).

Results In many cases of ASC-US (36.97\%) and ASC-H (40.50\%), no clinical actions were taken. Cytology was the most frequent follow-up chosen, including for cases of ASC-H, which goes against the conduct recommended in the national guideline. In women over 30 years of age, the period of time elapsed between an ASC-US result and a new cytology was in 13.03 months, in disagreement with the national guideline recommendations $(p<0.0001)$. Negative for intraepithelial lesions or malignancy (NILM) cytologic $(p=0.0026)$ and histologic $(p=0.0017)$ results in the follow-up were associated with prior ASC-US, while negative results for ASC-H were cytologically $(p<0.0001)$ and histologically associated with high-grade squamous intraepithelial lesion (HSIL) $(p<0.0001)$. Two invasive cervical carcinomas (ICCS) were found in the follow-up for ASC-H, and there was a statistically significant association $(p=0.0341)$. A positive HR-HPV test was associated with ASC-H $(p=0.0075)$.

Conclusion The data suggest that even for a population of Brazilian women assisted at private clinics, the national guidelines recommendations for ASCs results are not followed.
\end{abstract}

received

November 10, 2017

accepted

February 7, 2018

published online

March 19, 2018
DOI https://doi.org/

10.1055/s-0038-1639466. ISSN 0100-7203.
Copyright $@ 2018$ by Thieme Revinter

Publicações Ltda, Rio de Janeiro, Brazil
License terms

(c) (i) $\ominus$ (\$) 


\section{Resumo}

\section{Palavras-chave}

- neoplasia cervical uterina

- manejo de doenças

- células escamosas atípicas do colo do útero

- teste de papanicolau

- papilomavírus humano
Objetivo Avaliar a conduta adotada por ginecologistas após resultados citológicos apresentando células escamosas atípicas (ASCs) e os desfechos destes casos em mulheres brasileiras.

Métodos Um estudo observacional prospectivo avaliou o manejo clínico inicial do ginecologista nos casos de 2.458 resultados citológicos apresentando ASCs coletados entre janeiro de 2010 e julho de 2016. Os respectivos desfechos citológicos, histológicos e de detecção do papilomavírus humano (HPV) foram comparados entre os subgrupos células escamosas atípicas de significado indeterminado (ASC-US) e células escamosas atípicas não podendo excluir lesão intraepitelial de alto grau (ASC-H).

Resultados Nenhuma conduta foi adotada em 36,97\% de citologias do tipo ASC-US e $40,5 \%$ do tipo ASC-H. A conduta mais escolhida foi a repetição da citologia, inclusive para acompanhamento de ASC-H, o que contraria as diretrizes nacionais. O tempo de realização de uma nova citologia para resultado do tipo ASC-US em mulheres com mais de 30 anos de idade foi de 13,03 meses, também em desacordo com as diretrizes $(p<0,0001)$. Resultados negativos para lesão intraepitelial ou neoplasia maligna (NILM), tanto citológicos $(p=0,0026)$ como histológicos $(p=0,0017)$, foram associados a ASC-US, enquanto que resultados negativos para lesões intraepiteliais escamosas de alto grau (HSILs), citológicos $(p<0,0001)$ e histológicos, foram associados a ASC-H $(p<0,0001)$. Dois carcinomas cervicais invasivos foram encontrados durante o acompanhamento para ASC-H e uma associação estatisticamente significante foi estabelecida $(p=0,0341)$. Um teste de HR-HPV positivo foi associado a ASC-H $(p=0,0075)$.

Conclusão Os dados sugerem que mesmo para uma população de mulheres brasileiras atendidas em clínicas privadas, as recomendações das diretrizes clínicas nacionais para resultados citológicos apresentando ASCs não são seguidas.

\section{Introduction}

Despite being preventable, uterine cervical cancer persists as an important cause of women's morbidity and mortality, especially in developing countries. ${ }^{1}$ Since it was adopted as a screening method in the middle of the last century, the Papanicolaou (PAP) test remains a preferred method of screening and has reduced the incidence and mortality of cervical cancer; ${ }^{2}$ however, this fundamental procedure presents a high variation of sensitivity and reproducibility for the detection of cancer precursor lesions. ${ }^{3}$ In addition to this limitation, the spectrum of cytological diagnoses also presents a group of atypical squamous cell findings, whose cytomorphological changes do not allow a definitive diagnosis. Therefore, there remains a gray area of persistent controversy among both gynecologists and cytopathologists. ${ }^{4,5}$

The Bethesda System (TBS) recognizes two atypical diagnoses in squamous cells: atypical squamous cells of undetermined significance (ASC-US), which occurs when there is uncertainty between findings of reactive changes and lowgrade squamous intraepithelial lesion (LSIL), and atypical squamous cells-cannot exclude high-grade squamous intraepithelial lesion (ASC-H), which is identified when the doubt is whether it is an immature and reactive metaplasia or a high-grade intraepithelial lesion (HSIL) ${ }^{6,7}$ In fact, these cytological abnormalities are not defined as a specific biological entity, but as result of an interpretive uncertainty; they do not even have a corresponding histopathological description. $^{8}$ Thus, the cytologic diagnosis remains inconclusive, and this leads to a clinical dilemma regarding the best way of managing such cases. ${ }^{5,9}$

The number of patients lost to cervical cancer screening follow-ups is greater in developing countries, and it has been reported that a delay in the diagnosis of this cancer is correlated with lower survival rates. Several factors such as socioeconomic status, access to healthcare facilities, prior partner permission and family history may affect a screening program success, but a previous health guidance is crucial to enable a patient's return, especially in the case of dubious results, such as ASCs. ${ }^{10,11}$

Referral to colposcopy/biopsy may burden the health system too much, since many low-grade lesions clear up spontaneously. On the other hand, many patients with atypical findings may correspond to high-grade lesions or even invasive cervical cancer (ICC). ${ }^{2}$ In Brazil, the Ministry of Health(MS) and the National Cancer Institute (INCA) ${ }^{12}$ recommend that a cytology with an ASC-US result should be repeated in a variable time depending on the patient's age, and, in the case of ASC-H, the recommendation is for a colposcopy to be performed, regardless of the age of the patient. 
This study aims to determine what methods are chosen after an ASCs cytology and to evaluate the outcomes of cases diagnosed with ASC-US and ASC-H over a 6-year period from a private health service in a large city in northeastern Brazil.

\section{Methods}

This is an observational and prospective study exclusively performed on laboratory database records of cases diagnosed as ASCs between January of 2010 and July of 2016 in the city of Fortaleza (Brazil) and, therefore, informed consent was not necessary. It was approved by the Ethics and Research Committee of the Federal University of Ceará (protocol number: 55957716.3.0000.5054).

The case records were scrutinized form a database to determine, for each ASCs cytology, the respective clinical management and results. Samples from $\sim 163$ gynecologists were assessed. Patients of any age who were not currently pregnant or immunocompromised were included. Altogether, 2,458 cervical samples with ASCs results were analyzed at the laboratory, and only one was excluded due Cushing syndrome.

All smears were collected using Liquid-Based Cytology by SurePath (BD, Franklin Lakes, N.J., USA) or Pap Smear, and the interpretations followed the TBS nomenclature. The HPV tests from the database were performed by Hybrid Capture 2 (HC2) (Qiagen AG, Hombrechtikon, Switzerland) or real-time polymerase chain reaction (PCR). The HC2 test was performed for high-risk (HR) HPV (genotypes 16, 18, 31, 33, 35, 39, 45, 51, 52, $56,58,59,68)$. Expression was measured as the reactive light unit (RLU). The Cobas 4800 system (Roche Diagnostics, Pleasanton, CA, USA) with three channels (HPV16, HPV18, or other 12 HR HPV types) was used according to the manufacturer's instructions.

The analysis of the management was based (until July 2011) on the consensus of the Brazilian Nomenclature for Cervical Reports and Recommended Practices of 2006; after July 2011, the 2011 Brazilian guidelines for the cervical cancer screening of INCA were used because they were applicable at the time of data collection.

To verify if the clinical management for ASC-US followed the current protocols, the data was separated into two groups: repeat cytology at 12 months for those under
30 years of age from August 2011 onwards and repeat cytology at 6 months for the remaining patients.

To evaluate the absence of evolution data in the sample, the patient records for those aged 30 years or over whose ASC-US results were collected up to 6 months before the end date of the study were excluded. Similarly, those patients aged less than 30 years whose ASC-US results were collected up to 12 months before the end date of the study were excluded, and patients aged less than 30 years with ASC-H cytology whose data were collected within 6 months before the end date of the study were also excluded. These exclusions were performed because the absence of data in these cases would be expected.

Statistical analyses were performed using the GraphPad Prism software, version 6.0 (Graph-Pad Software Inc., San Diego, CA, USA). The mean and standard deviations were used for continuous variables. The Fisher exact test was applied for binomial variables, and a one-sample Student $t$-test was performed for continuous variables; the $95 \%$ confidence intervals (CIs) were used, and results were considered as statistically significant when $p<0.05$.

\section{Results}

For the ASC-US group, the ages of the patients ranged from 14 to 85 years, with a mean of 33.12 years $( \pm 11.28)$; for the ASC$\mathrm{H}$ group, the mean age was 37.10 years $( \pm 12.86)$, and they ranged from 17 to 82 years.

After applying the exclusion criteria to verify absence of evolution, the ASC-US results were 1,998. Among these specific cases, 739 (36.97\%) did not present any evolution examination results to assess the clinical management that followed. There was also no follow-up for ASC-H patients in 98 out of 242 records ( $40.50 \%$ ).

Regarding the Pap smear method, the data that contained follow-up information indicated that a repeat cytology was the most frequent management for the ASC-US group (66.72\%). Cytology was also the most frequent evolution in cases of ASC-H ( 85 registers; 59.02\%). The isolated biopsy was the only method that showed statistical significance between the groups, with 17 (11.81\%) ASC-H records $(p=0.0112)$ (-Table 1).

Table 1 Atypical squamous cells subgroups and performed management $(n=1,403)$

\begin{tabular}{|l|l|l|l|l|}
\hline Evolution & $\begin{array}{l}\text { ASC-US } \\
\mathbf{n}(\%)\end{array}$ & $\begin{array}{l}\text { ASC-H } \\
\mathbf{n}(\%)\end{array}$ & $\begin{array}{l}\text { p-value } \\
(\mathrm{Cl} \text { 95\%) }\end{array}$ \\
\hline Cytology & $840(66.72)$ & $85(59.02)$ & 0.0775 & $1.036(0.9960-1.078)$ \\
\hline Cytology + DNA-HPV & $133(10.56)$ & $13(9.02)$ & 0.6662 & $1.017(0.9634-1.073)$ \\
\hline DNA-HPV & $202(16.04)$ & $28(19.44)$ & 0.2868 & $1.231(0.8353-1.814)$ \\
\hline Biopsy & $74(5.88)$ & $17(11.81)$ & 0.0112 & $1.930(1.219-3.056)$ \\
\hline Biopsy + DNA-HPV & $10(0.79)$ & $1(0.69)$ & 1.0000 & $1.018(0.8397-1.222)$ \\
\hline Total & $1,259(100.00)$ & $144(100.00)$ & & \\
\hline
\end{tabular}

Abbreviations: ASC-US, atypical squamous cells of undetermined significance; ASC-H, atypical squamous cells cannot exclude high grade squamous intraepithelial lesion; $\mathrm{Cl}$, confidence interval.

Fisher exact test. Statistical significance $-p<0.05$. 
Table 2 Cytology results as a follow-up from a prior atypical squamous cells result $(n=1,071)$

\begin{tabular}{|l|l|l|l|l|}
\hline & $\begin{array}{l}\text { ASC-US } \\
\mathbf{n}(\%)\end{array}$ & $\begin{array}{l}\text { ASC-H } \\
\mathbf{n}(\%)\end{array}$ & $\begin{array}{l}\text { p-value } \\
(\mathrm{Cl} 95 \%)\end{array}$ \\
\hline NILM & $856(87.98)$ & $75(76.53)$ & 0.0026 & $1.100(1.020-1.187)$ \\
\hline ASC-US & $50(5.14)$ & $4(4.08)$ & 0.8110 & $1.020(0.9437-1.103)$ \\
\hline ASC-H & $2(0.21)$ & $3(3.06)$ & 0.0065 & $6.733(3.209-14.13)$ \\
\hline AGCS & $3(0.31)$ & $2(2.04)$ & 0.0690 & $4.442(1.492-13.22)$ \\
\hline LSILS & $57(5.86)$ & $5(5.10)$ & 1.0000 & $1.013(0.9383-1.093)$ \\
\hline HSILS & $5(0.51)$ & $9(9.18)$ & $<0.0001$ & $7.635(4.926-11.83)$ \\
\hline Total & $973(100)$ & $98(100)$ & & \\
\hline
\end{tabular}

Abbreviations: AGCs, atypical glandular cells; ASC-H, atypical squamous cells cannot exclude high grade squamous intraepithelial lesion; ASC-US, atypical squamous cells of undetermined significance; $\mathrm{Cl}$, confidence interval; HSILs, High-grade squamous intraepithelial lesions; LSILs, low-grade squamous intraepithelial lesions; NILM, negative for intraepithelial lesion or malignancy.

Fisher exact test. Statistical significance $-p<0.05$.

According to national guidelines for ASC-US management, a repeat cytology is required within 6 or 12 months. The protocol for 712 patients demanded a 6-month cytology repeat, and the mean gap between both cytologies was 13.03 months ( \pm 11.26$)$, ranging from 1 to 73 months. By applying a one-sample Student $t$-test to compare with the 6-month parameter, a statistically significant difference was observed between cytology means and the means expected for the age group $(p<0.0001)$. Data from 303 patients with ASC-US cytology results whose recommendation was to repeat the test at 12 months revealed that the mean cytology repeat time was 11.89 months $( \pm 8,68)$, ranging from 2 to 52 months. There is no statistically significant difference between the mean cytology repeat time obtained and the recommended by the national guidelines $(p=0.8324)$.

For ASC-US cases, out of the 973 patients followed-up with a repeat cytology, 856 (87.98\%) were negative for intraepithelial lesion or malignancy (NILM), 50 remained ASCUS (5.14\%), 57 (5.86\%) presented a cytological diagnosis of LSIL and $5(0,51 \%)$ presented HSIL in the follow-up cytology. For the ASC-H group, there were 98 cases out of which 75 (76.23\%) were NILM, and 9 (9.18\%) were HSILs. The NILM result in cytological follow-up for ASC-US is significantly more frequent than for ASC-H. It was significantly more frequent for ASC-H that the cytology remained ASC-H or progressed to HSIL (- Table 2).
In $\sim 148$ biopsies performed after an ASC-US cytology, a predominance of NILM (65.54\%) and LSIL (22.30\%) was observed, and NILM was found to be more significant in this group than in the ASC-H group. The gap between the cytology and the biopsy was on average $4.2( \pm 4.4)$ months, ranging from 1 to 26 months. The biopsy results, such as the ones performed as follow-up of ASC-H cytology, showed that in half of the cases, the histopathological examination resulted in HSIL or higher. The histopathological finding of HSIL was significantly more frequent in the ASC-H group. The results are shown in - Table 3.

A total of 441 patients with ASC-US cytology underwent a high-risk-HPV (HR-HPV) test for the follow-up. Of these, 219 (49.66\%) had positive HR-HPV at follow-up. The 58 patients with ASC-H cytology were followed-up with a HR-HPV molecular test, and in 40 (68.97\%) cases, the test was positive. The HR-HPV test positivity was significantly higher for the ASC-H group ( - Table 4).

\section{Discussion}

Cervical cancer is a well-known and preventable malignity, ${ }^{13}$ and yet, failure to reach women with particular age risks as well as losses of follow-up can lead to irreparable damage. In the United States, nearly half of the women with invasive

Table 3 Histopathological result as a follow-up from a previous atypical squamous cells cytology $(n=182)$

\begin{tabular}{|l|l|l|l|l|}
\hline & $\begin{array}{l}\text { ASC-US } \\
\mathbf{n}(\%)\end{array}$ & $\begin{array}{l}\text { ASC-H } \\
\mathbf{n}(\%)\end{array}$ & -value & $\begin{array}{l}\text { Relative Risk } \\
(\mathrm{Cl} 95 \%)\end{array}$ \\
\hline NILM & $97(65.54)$ & $12(35.29)$ & 0.0017 & $1.274(1.081-1.502)$ \\
\hline LSILs & $33(22.30)$ & $5(14.71)$ & 0.4825 & $1.087(0.9373-1.262)$ \\
\hline HSILs & $18(12.16)$ & $15(44.12)$ & $<0.0001$ & $3.565(2.031-6.255)$ \\
\hline Invasive Cancer & $0(0.00)$ & $2(5.88)$ & 0.0341 & $5.625(4.108-7.702)$ \\
\hline Total & $148(100)$ & $34(100)$ & & \\
\hline
\end{tabular}

Abbreviations: ASC-H, atypical squamous cells cannot exclude high grade squamous intraepithelial lesion; ASC-US, atypical squamous cells of undetermined significance; HSILs, High-grade squamous intraepithelial lesions; LSILs, low-grade squamous intraepithelial lesions; NILM, negative for intraepithelial lesion or malignancy.

Fisher exact test. Statistical significance $-p<0.05$. 
Table 4 High risk-HPV test result as a follow-up from a previous atypical squamous cells cytology $(n=499)$

\begin{tabular}{|l|l|l|l|l|}
\hline HPV test & $\begin{array}{l}\text { ASC-US } \\
\mathbf{n}(\%)\end{array}$ & $\begin{array}{l}\text { ASC-H } \\
\mathbf{n}(\%)\end{array}$ & p-value & $\begin{array}{l}\text { Relative Risk } \\
\text { (Cl 95\%) }\end{array}$ \\
\hline Positive & $\begin{array}{l}219 \\
(49.66)\end{array}$ & $\begin{array}{l}40 \\
(68.97)\end{array}$ & 0.0075 & $\begin{array}{l}2.059 \\
(1.215-3.491)\end{array}$ \\
\cline { 1 - 3 } Negative & $\begin{array}{l}222 \\
(50.34)\end{array}$ & $\begin{array}{l}18 \\
(31.03)\end{array}$ & & \\
\hline Total & $\begin{array}{l}441 \\
(100)\end{array}$ & $\begin{array}{l}58 \\
(100)\end{array}$ & & \\
& & & \\
\hline
\end{tabular}

Abbreviations: ASC-US, atypical squamous cells of undetermined significance; ASC-H, atypical squamous cells cannot exclude high-grade squamous intraepithelial lesion; $\mathrm{Cl}$, confidence interval.

Fisher exact test. Statistical significance $-p<0.05$.

HPV test by HC2 (Qiagen) and Real time PCR (Cobas 4000).

cervical cancer diagnoses have never been screened, and an additional $10 \%$ of cancer cases occurred among untracked women in the last 5 years. ${ }^{14}$ The goal of cytology management with an ASCs result is to find patients who may present high-grade lesions or even underlying ICC. However, there is no single globally acceptable strategy for these cases. The ASC-US management includes repeat cytology, colposcopy and/or a HPV test, ${ }^{5,15}$ while ASC-H requires a prompt colposcopy to be performed. ${ }^{16}$

To be effective, a screening program depends on the adequate follow-up of women with abnormal cytopathologic findings, and the Brazilian program for the control of cervical cancer has been described as ineffective. ${ }^{17,18}$ This study showed that no clinical management was found for $36.97 \%$ of ASC-US patients and for $40.50 \%$ ASC-H patients. This may occur for different reasons, but we believe that it is due to the lack of clinical uniformity, and inadequate information to the patients about the risks of this temporary diagnosis of ASCs. Other Brazilian authors also observed that women with Pap test abnormalities are not adequately targeted or referred according to the national guidelines. ${ }^{17}$

This paper sought to assess whether the cytological repeat procedure followed the current national protocol. Until the launching of the Brazilian Guidelines for Cervical Cancer Screening, in July 2011, the consensus was that described in the Brazilian Nomenclature for Cervical Reports and Recommended Procedures, which recommended a repeat cytology in 6 months, regardless of age, for the ASC-US group. The 2011 guidelines indicated that, for women under 30 years of age, cytology should be repeated at 12 months, and the determination to repeat cytology should remain within 6 months for all other ages. ${ }^{17,19}$ For patients who were recommended a repeat cytology in 6 months, our results suggest that this was performed, on average, within 13.03 months, exhibiting a statistically significant difference in relation to the recommended time. No significant statistical difference was observed for the group with a recommendation for repeat cytology at 12 months, with a mean of 11.89 months. This result may indicate that repeat cytology management at 6 months has not occurred at the recommended time.
Due to the design of this study, we could not evaluate the gynecologist's conduct in the presence of an ASC-H diagnosis, which must be followed-up with a colposcopy. However, a substantial number of these patients will undergo biopsies, which in turn are performed in the laboratory. Selvaggi ${ }^{16}$ found that $64 \%$ of the patients who undergo colposcopy due to an ASC-H cytology result will require a biopsy. In our study, only $12.5 \%$ of the patients underwent biopsy, a frequency five times lower than that expected for those who underwent colposcopy, which suggests that the approach recommended in these cases was not followed.

Cytology was more frequently performed at follow-up for both groups. For ASC-US, it was performed in $77.28 \%$ of all managements, showing in most cases $(87.98 \%)$ no cytological abnormalities in the follow-up. This data supports the national recommendations of repeat cytology ASC-US cases, due to a low frequency of persistence of abnormalities. The persistence of the ASC-US diagnosis occurred in 5.14\% of the cases; this result is similar to that obtained in another study, ${ }^{9}$ which was slightly less frequent than the diagnosis of LSIL (5.86\%). For the ASC-US group, only $0.5 \%$ were HSILs, which is very similar to that obtained by another study ${ }^{20}$ that showed that, in general, the most common evolution of these cases is resolution and, exceptionally, progression. Our study pointed out that $9.18 \%$ of the ASC-H group exhibited HSIL. In an abstraction exercise, if this same frequency was found in patients without a follow-up in our study population, we would have 3.8 ASC-US patients and 9 ASC-H patients progressing to HSIL, completely ignoring their condition.

Biopsies may have been performed after the ASC-US cytology result as a follow-up of an abnormal prior cytology or based upon a recommendation of the gynecologist and indicated by colposcopic guidance, that is, subjected to a greater severity on demand of the specific case than for the other cases; this could result in a possible selection bias. The results of our analyses show a $12 \%$ finding of cervical intraepithelial neoplasia 2 (CIN 2) or superior; this is much more than that found in the repetition of a cytology, which was also superior to other studies. ${ }^{5,15}$ However, it is close to the results of Bountris et $\mathrm{al}^{21}$ in their meta-analysis. For histological follow-up from ASC-H cases, we found that CIN 2 or superior was diagnosed in half of the cases; also, in two ASC-H cases, an ICC was found. This is in accordance with results reported by a review of six studies (32-66\%). ${ }^{16}$ Another study regarding the follow-up of ASCs cytology found that ICC was significantly more associated with ASC-H. ${ }^{20}$

In Brazil, when cytology results show ASC-US, the recommended management is to perform a repeat cytology; however, other countries propose to perform HR-HPV testing. ${ }^{22}$ In our study, a HR-HPV test was performed as a follow-up procedure that was isolated or associated with another kind of follow-up in $27.39 \%$ of cases; positivity for HR-HPV was found in $49.66 \%$ of these cases. Watson et $\mathrm{al}^{23}$ analyzed the follow-up of 45,049 ASC-US Pap smears and reported $42 \%$ of HR-HPV positivity, which is very close to the result found by the systematic review of Arbyn et al, ${ }^{4}$ while the ALTS study reported a rate slightly above $50 \%{ }^{24}$ For ASC-H follow-up, positivity for HR-HPV (68.97\%) was below that reported in the ALTS study (85\%). ${ }^{2,6}$ 
The results of this study should be interpreted with caution. A weakness of this research was the impossibility of detecting when a follow-up consisted of a colposcopy, since this information was not included in the laboratory's database but only in medical records. Our analyses also cannot determine whether failure to perform a follow-up was due to the patients or their physician. Further studies are needed to assess the reality of ASCs management in Brazil, especially controlled studies.

\section{Conclusion}

Our results may indicate that ASCs management does not follow the national guidelines, and therefore, there are possible risks for the patients in our country. Also, the cytological, histological and HR-HPV positivity outcomes are in accordance with the values found in the literature.

\section{Conflicts to Interest}

The authors declare that there are no conflicts of interest.

\section{Contributors}

Oliveira G. G., Oliveira J. M. S. C., Eleutério R. M. N. and Eleutério Júnior J. contributed with project and interpretation of data, writing of the article, critical review of the intellectual content and final approval of the version to be published.

\section{References}

1 Wei H, Wang N, Zhang Y, Zhang J, Wang S, Zhang S. Distribution of various types of low-risk human papillomavirus according to cervical cytology and histology in northern Chinese women. Int J Gynaecol Obstet 2014;126(01):28-32. Doi: 10.1016/j.ijgo.2014.01.020

2 Kececioglu M, Seckin B, Baser E, et al. Cost and effectiveness comparison of immediate colposcopy versus human papillomavirus DNA testing in management of atypical squamous cells of undetermined significance in Turkish women. Asian Pac J Cancer Prev 2013;14(01):511-514

3 Persson M, Elfström KM, Olsson SE, Dillner J, Andersson S. minor cytological abnormalities and up to 7-year risk for subsequent highgrade lesions by HPV type. PLoS One 2015;10(06):e0127444. Doi: 10.1371/journal.pone.0127444

4 Arbyn M, Roelens J, Simoens C, et al. Human papillomavirus testing versus repeat cytology for triage of minor cytological cervical lesions. Cochrane Database Syst Rev 2013;(03): CD008054. Doi: 10.1002/14651858.CD008054.pub2

5 Paesi S, Correa L, Tregnago MC, Mandelli J, Roesch-Ely M. Human papillomavirus among women with atypical squamous cells of undetermined significance in southern Brazil. Int J Gynaecol Obstet 2015;128(01):23-26. Doi: 10.1016/j.ijgo.2014.07.027

6 Barcelos AC, Michelin MA, Adad SJ, Murta EF. Atypical squamous cells of undetermined significance: Bethesda classification and association with Human Papillomavirus. Infect Dis Obstet Gynecol 2011;2011:904674

7 Xu L, Verdoodt F, Wentzensen N, Bergeron C, Arbyn M. Triage of ASC-H: A meta-analysis of the accuracy of high-risk HPV testing and other markers to detect cervical precancer. Cancer Cytopathol 2016;124(04):261-272. Doi: 10.1002/cncy.21661

8 Schiffman M, Vaughan LM, Raine-Bennett TR, et al. A study of HPV typing for the management of HPV-positive ASC-US cervical cytologic results. Gynecol Oncol 2015;138(03):573-578. Doi: 10.1016/j.ygyno.2015.06.040

9 López-Alegría F, Poblete OQ De Lorenzi DS, Oyanedel JC. Clinical management of the first ASCUS report in Chile. Prospective single-cohort study. Sao Paulo Med J 2015;133(06):480-487. Doi: 10.1590/1516-3180.2014.9142511

10 Joseph N, Hinchcliff E, Goodman A. Cervical cancer screening: the challenges of tracking and follow-up. J Genit Syst Disord 2015;4 (04):4. Doi: 10.4172/2325-9728.1000144

11 Bindu T, Kumar SS, Ratheesan K, Balasubramanian S. Factors associated with survival and lost to follow-up of cervical cancer patients in a tertiary cancer centre in rural Kerala. Indian J Public Health 2017;61(01):43-46. Doi: 10.4103/0019-557X.200254

12 Ministério da Saúde. Instituto Nacional de Câncer José Alencar Gomes da Silva. Diretrizes brasileiras para o rastreamento do câncer do colo do útero. 3rd ed. Rio de Janeiro, RJ: INCA; 2016

13 Tsu V, Jerónimo J. Saving the world's women from cervical cancer. NEngl J Med 2016;374(26):2509-2511. Doi: 10.1056/NEJMp1604113

14 Saslow D, Solomon D, Lawson HW, et al. American Cancer Society, American Society for Colposcopy and Cervical Pathology, and American Society for Clinical Pathology screening guidelines for the prevention and early detection of cervical cancer. J Low Genit Tract Dis 2012;16(03):175-204

15 Tokmak A, Guzel AI, Ozgu E, et al. Clinical significance of atypical squamous cells of undetermined significance in detecting preinvasive cervical lesions in post- menopausal Turkish women. Asian Pac J Cancer Prev 2014;15(16):6639-6641

16 Selvaggi SM. Clinical significance of atypical squamous cells cannot exclude high grade squamous intraepithelial lesion with histologic correlation-: a 9-year experience. Diagn Cytopathol 2013;41(11):943-946. Doi: 10.1002/dc.22982

17 Albuquerque ZBP, Manrique EJC, Tavares SBN, Silva e Souza AC, Guimarães JV, Amaral RG. [Women with atypical, precursor lesions and invasive cervical cancer: behaviors according to the recommendations of the Ministry of Health]. Rev Bras Ginecol Obstet 2012;34(06):248-253. Doi: 10.1590/S0100-72032012000600002

18 Leinonen MK, Campbell S, Klungsøyr O, Lönnberg S, Hansen BT, Nygård M. Personal and provider level factors influence participation to cervical cancer screening: A retrospective registerbased study of 1.3 million women in Norway. Prev Med 2017; 94:31-39. Doi: 10.1016/j.ypmed.2016.11.018

19 Ministério da Saúde. Instituto Nacional de Câncer. Diretrizes brasileiras para o rastreamento do câncer do colo do útero. Rio de Janeiro, RJ: INCA; 2011

20 Pity IS, Shamdeen MY, Wais SA. Follow up of atypical squamous cell Pap smears in Iraqi women. Asian Pac J Cancer Prev 2012;13 (07):3455-3460

21 Bountris P, Haritou M, Pouliakis A, et al. An intelligent clinical decision support system for patient-specific predictions to improve cervical intraepithelial neoplasia detection. BioMed Res Int 2014;2014:341483

22 Preisler S, Rebolj M, Untermann A, et al. Prevalence of human papillomavirus in 5,072 consecutive cervical SurePath samples evaluated with the Roche cobas HPV real-time PCR assay. PLoS One 2013;8(03):e59765. Doi: 10.1371/journal.pone.0059765

23 Watson M, Benard V, Lin L, Rockwell T, Royalty J. Provider management of equivocal cervical cancer screening results among underserved women, 2009-2011: follow-up of atypical squamous cells of undetermined significance. Cancer Causes Control 2015;26(05): 759-764. Doi: 10.1007/s10552-015-0549-9

24 Veijalainen O, Tuomisaari S, Luukkaala T, Mäenpää J. High risk HPV testing in the triage of repeat ASC-US and LSIL. Acta Obstet Gynecol Scand 2015;94(09):931-936. Doi: 10.1111/aogs.12686 